\title{
Factors influencing the compliance of taxpayers
}

Neni Meidawati

Accounting Department, Universitas Islam Indonesia, Yogyakarta, Indonesia

neni.meidawati@uii.ac.id

Muhammad Nurul Azmi

Accounting Department, Universitas Islam Indonesia, Yogyakarta, Indonesia

Follow this and additional works at: https://journal.uii.ac.id/jca

Copyright (C2019 Journal of Contemporary Accounting and Authors.

To cite this article: Neni Meidawati \& Muhammad Nurul Azmi. (2019). Factors influencing the compliance of taxpayers. Journal of Contemporary Accounting, 1(1), 26-37. doi:10.20885/ica.vol1.iss1.art3 


\title{
Factors influencing the compliance of taxpayers
}

\author{
Neni Meidawati ${ }^{1}$, Muhammad Nurul Azmi ${ }^{2}$ \\ 1,2 Accounting Department, Universitas Islam Indonesia, Yogyakarta, Indonesia
}

\author{
JEL Classification: \\ M41, M48 \\ Keywords: \\ Compliance, knowledge, awareness, tax \\ sanction
}

\section{Corresponding Author: \\ neni.meidawati@uii.ac.id \\ DOI: \\ 10.20885/ica.vol1.iss 1.art3}

Copyright (C) 2019

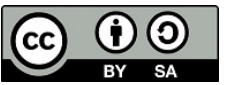

This is an open access under CC-BY-SA license

\begin{abstract}
The compliance in tax reporting of an individual taxpayer who is running business or having freelance job is one of the ways to maximize the tax revenue in Indonesia. This research aims to examine the factors that affect the tax reporting compliance of an individual taxpayer who is running business or having freelance work. The data were collected by distributing questionnaires. The regression model used in this study was multiple linear regression using SPSS. The sampling method was random sampling which involved 47 individual taxpayers who were already registered at Tax Service Office (KPP) Pratama Pontianak with an error rate of $5 \%$. The result showed that level of awareness had positive and significant influence on tax reporting compliance of the individual taxpayers at KPP Pratama Pontianak who are running business and doing freelance work. Meanwhile, tax knowledge and tax sanction had no effect toward tax reporting compliance of the individual taxpayers running business and doing freelance work.
\end{abstract}

\section{Introduction}

The prominent source of the state revenue as stated in the State Budget is tax; consequently, the Government of Indonesia keeps promoting the state revenue through tax (Arum, 2012). The Ministry of Finance of the Republic of Indonesia has recorded tax revenues in the first quarter of 2018 capable of growing by $9.94 \%$ with a achievement of $\mathrm{Rp} 244.5$ trillion or $17.6 \%$ of the target of the 2018 State Budget (APBN) which amounted to Rp 1,618.1 trillion (Kontan.co.id, 2018). The attempts which were performed by the government included law enforcement and taxation regulations improvement, taxation system using self assessment system, and taxation information dissemination to enhance the compliance of taxpayers, who both had and did not have tax registration numbers.

The government keeps improving the taxpayers' compliance in annual tax report submission (SPT), tax payment punctuality, and expected calculation/reporting. The impacts of low-level taxpayers' compliance are the decrease in state revenue from tax, less prospective taxation system, and unreliable taxation system as the source of state income (Rustiyaningsih, 2012). Therefore, the government has issued and sent tax warning/reprimand letter/tax collection order, dissemination of information on tax entitlement and obligation, and gratitude letter to the taxpayers who punctually submitted their annual tax reports. The level of awareness also influences tax compliance, where the higher the level of community awareness of tax reporting, the higher its tax compliance level. (Dewi \& Merkusiwati, 2018; Rahmanto, 2014).

Tax knowledge is the tax information which can be used by taxpayer as the basis to act, make decision, and take a particular direction or strategy to perform his rights and obligations in taxation. The level of knowledge on taxation affects the taxpayers' compliance. Low level of taxpayers' taxation knowledge will result in less awareness to report the tax due and cause less payment than the amount the taxpayers should pay. In addition, the always-modernized tax administration system also requires the community to adapt. The ease of technology is currently provided by using an e-filling system to increase the level of tax compliance (Setiawan et al., 2018). 
On the other hand, lack of information dissemination leads to the low level of taxation knowledge. There are many taxpayers who still do not understand the importance of tax for the country. As a result, their contribution in tax compliance is also minimum. On the other hand, if the taxpayers have higher level of knowledge on taxation procedures, functions, and roles, they will comply more with reporting their tax obligation (Ginting, 2017; Khasanah \& Novi, 2016; Rahmanto, 2014; Setiyani et al., 2018).

The enforcement of sanction to the offenders will be a shock therapy since the sanction implementation aims to improve the taxpayers' compliance. Generally, the sanction will bring loss for the offenders. Tax sanction was proven to have a positive effect on the taxpayers' compliance in reporting their taxes (Dewi \& Merkusiwati, 2018; Erawati \& As'ari, 2018; Kusuma, 2010).

The rate of taxpayers' compliance in 2017 reached 72.41\% (TribunPontianak.com, 2018). The result was not yet maximum. According to Institute for Development of Economics and Finance (INDEF), the economic growth of West Kalimantan in 2018 was more prospective compared to other provinces in Kalimantan due to its more stable local economic performance. The economic growth rate of West Kalimantan was recorded $7 \%$ or higher than the national economic growth rate. However, the compliance level of the individual taxpayers who were running business or doing freelance work in Pontianak was still very low as the Head of Tax Service Office (KPP) Pratama Pontianak stated that the level of awareness of the individual taxpayers categorized as non-employee was still so low that the target of tax realization of Pontianak Tax Service Office in 2017 could not be realized. Out of 45,000 non-employee individual taxpayers, only 20,000 people reported their taxes. Therefore, an intensive monitoring is badly needed for the non-employee taxpayers who run professional business such as lawyer, accountant, doctor, notary, teacher, and online business people.

\section{Literature Review and Hypothesis Development}

\section{Theory of Attribution}

Attribution is a process where someone draws a conclusion on the factors influencing other people's behavior. Attribution is also a way to explain the cause of his/her own or other's behavior or a process to create an individual image. Tax compliance can be interpreted into the behavior of taxpayer in perceiving tax. The perception is influenced by the internal and external conditions of the taxpayer. Theory of attribution states that if individuals observe the behavior of other individual, they try to determine whether the behavior is caused by internal or external factors (Suntono et al., 2015). This theory was once established by Heider (1958). The theory assume that an individual will try to seek the cause of an action which people do what so called attribution to the behavior. Theory of attribution is categorized into three types according to Robbins (1996), namely (1) Particularity, where an individual will perceive other individual's behavior differently in different situations. If an individual behavior is considered as exceptional, other individual acting as an observer will assume as external attribution to the behavior. On the other hand, if the behavior is considered as usual, it will then be assumed as internal attribution; (2) Consensus, where every person has the same perception on an individual behavior in the same situation. If the level of consensus is high, it can be categorized as internal attribution; in contrast, the low level of consensus will be categorized as external attribution; (3) Consistency, if an individual perceives the behaviors of others with the same responses from time to time. The more consistent the behavior, the more people will relate that to the internal causes.

\section{Definition of Taxation}

According to Law Number 28 of 2007 Article 1, tax is defined as a mandatory contribution owed to the state which is imposed on an individual or an entity. Tax is a compulsory levy or tariff collected by the government from the community (taxpayers) to cover the state routine expenditures and development charge without remuneration which can be directly designated (Suprianto, 2011). 


\section{Knowledge on Taxation}

Knowledge on taxation is knowledge about the concepts of general provisions in taxation, types of taxes prevailing in Indonesia including subject of tax, object of tax, tax tariff, computation of tax payable, recording of tax payable, and how to fill in tax report. Setiyani et al. (2018) revealed that there were a number of indicators of taxation knowledge, namely: (1) Knowledge on the deadline of tax payment and reporting; (2) Knowledge on taxation general provisions and procedures; and, (3) Knowledge on taxation system.

\section{Level of Awareness}

According to Muliari and Setiawan (2011), a taxpayer can be called having awareness if the conditions below are fulfilled:

1. Being aware of the existence of taxation laws and provisions

2. Being aware of the function of tax for state expenditures

3. Being aware that the tax obligation must be implemented based on the prevailing regulations

4. Being aware of the function of tax for state financing

5. Calculating, paying, and reporting tax voluntarily

6. Calculating, paying, and reporting tax correctly

Several forms of awareness of paying tax which encourage the taxpayer to report tax are: First, awareness of tax as a form of participation in state development. By being aware of that, the taxpayer is willing to pay tax since he/she does not incur loss due to the tax collection; Second, awareness of that tax reporting delay and tax reduction will bring loss to the state. The taxpayer is willing to pay tax because he/she understands that the delay and reduction of tax payment will result in lack of financial resource which leads to disruptive national development; Third, awareness of tax laws and regulations which is compulsive in nature. The taxpayer will pay tax because he/she is aware that there is a strong legal basis for tax collection and it is an absolute obligation for all citizens. The larger the income of a corporate in one accounting period, the higher the level of complexity it has. The use of accounting information will be very helpful in managing the complexity in a company (Arum, 2012).

\section{Tax Sanction}

Erawati and As'ari (2018) assumed that tax sanction was a guarantee that the provisions of taxation rules and regulations (taxation norms) would be followed/obeyed/complied with. In other words, tax sanction was a preventive tool in order to keep taxpayers from violating taxation norms. Each possible violation, either minimum or maximum, has already been regulated in Laws Number 28 of 2007 along with the sanction. The regulations were made to minimize the possible violations which might be perpetrated by taxpayers and tax officials, and based on the fifth pillar of Pancasila, social justice for all Indonesian citizens. Also, the justice enforcement was implemented to motivate the taxpayers to obey the rules, therefore, the strict application of tax sanction was crucially needed to improve the tax awareness and compliance of the community.

Muliari and Setiawan (2011) stated that the perceptions of taxpayers about tax sanction could be measured using the indicators as followed.

a) Criminal sanction applied on the violator of tax regulations was quite severe.

b) Administration sanction applied on the violator of tax regulations was very mild.

c) The application of quite severe sanction was one of the measures to educate the taxpayers.

d) Tax sanction had to be applied on the violators without any tolerance.

e) The application of tax sanction could be negotiated.

There has been a common opinion in the community that the tax sanction will be imposed if ones do not pay taxes only. In fact, there are many other tax violations where sanctions can be 
imposed which include administrative sanction, such as interest increase, fines, and tariff increase as well as criminal sanction (Arum, 2012).

Arum (2012) also argued that there were four qualities expected or demanded from a taxpayer, namely:

1. Compliance of the taxpayer to report his/her tax with full awareness

2. Responsibility of the taxpayer to submit Tax Statement punctually as stated in Article 3 of Law Number 6/1983

3. Honesty of the taxpayer in filling in the Tax Statement

4. More severe law enforcement for the taxpayer violating the prevailing regulations.

\section{Taxpayer's Compliance}

According to General Dictionary of Indonesian (KBBI), comply means subject to or abide by a particular teaching or regulation. Jatmiko (2006) mentioned that compliance was a motivation of an individual, group, or organization to do or not to do things as stipulated in the regulation. An individual compliance was an interaction between individual, group, and organization behaviors. Thus, it could be said that tax compliance was an individual or taxpayer's compliance with the taxation laws and regulations.

There are two types of compliance according to Rustiyaningsih (2012), those are formal compliance and material compliance. Formal compliance is a situation where a taxpayer fulfills his/her formal responsibility as stated in the tax regulations. Material compliance is a situation where a taxpayer meets all of the taxation provisions' materials which refer to the contents and soul of taxation laws. Material compliance can also involve formal compliance. Formal compliance can be seen from the percentage of Tax Statement submissions of taxpayers because it is related to formal obligation in reference with taxation laws and regulations.

Muliari and Setiawan (2011) stated that there were some criteria of an obedient taxpayer according to Regulation of Minister of Finance No. 544/KMK.04/2000 as follows:

1) Punctually submitting Tax Statements for all types of taxes in the last two years

2) No overdue payables for all types of taxes, with the exception for those who are permitted to pay in installment or to delay tax payment

3) Never undergoing imprisonment due to tax violation in the last ten years

4) Implementing accounting for the last two years and undergoing examination and correction in each type of taxes owed at the maximum of five percent

5) Financial Statement under category of unqualified or qualified as long as not influencing fiscal profit and loss for the taxpayers whose financial reports were audited by public accountant for the last two years.

\section{Individual Taxpayers who is Running Business or Doing Freelance Work}

Arum (2012) defined that an individual taxpayer who was running business or doing freelance work was someone who was doing his/her work without any binding whatsoever with the work provider. Running business here means that the taxpayer has a business in a particular sector, such as trade, creative economy, and others. Meanwhile, freelance work is a work done by an individual with a particular skill as his/her income source without any specific work relations. The examples of freelance works are accountant, doctor, lawyer, and consultant. Freelance work is performed under someone's private name. If a person only works as an employee, such as accountant in Public Accountant Office, he/she is not categorized as an individual taxpayer who is doing freelance work. 


\section{Hypotheses}

\section{Influence of knowledge on taxation on individual taxpayer's compliance}

From the definition about knowledge on taxation, it can be concluded that knowledge on taxation is the information which can be used by a taxpayer as the basis to act, make decision, and take a particular direction or strategy in relation with the implementation of his/her rights and obligations on taxation.

Theory of attribution states that when an individual observes other's behavior, the individual tries to determine whether the behavior is influenced by internal or external factors. Internal factors come from

In regard with the theoretical bases and literature review above mentioned, this study is to analyze the influences of knowledge on taxation, level of awareness, tax sanction on Individual Taxpayer's Compliance who is running business and doing freelance work in the area of KPP Pratama Pontianak. A research model describing the relations among the variables to be tested is presented in Figure 1.

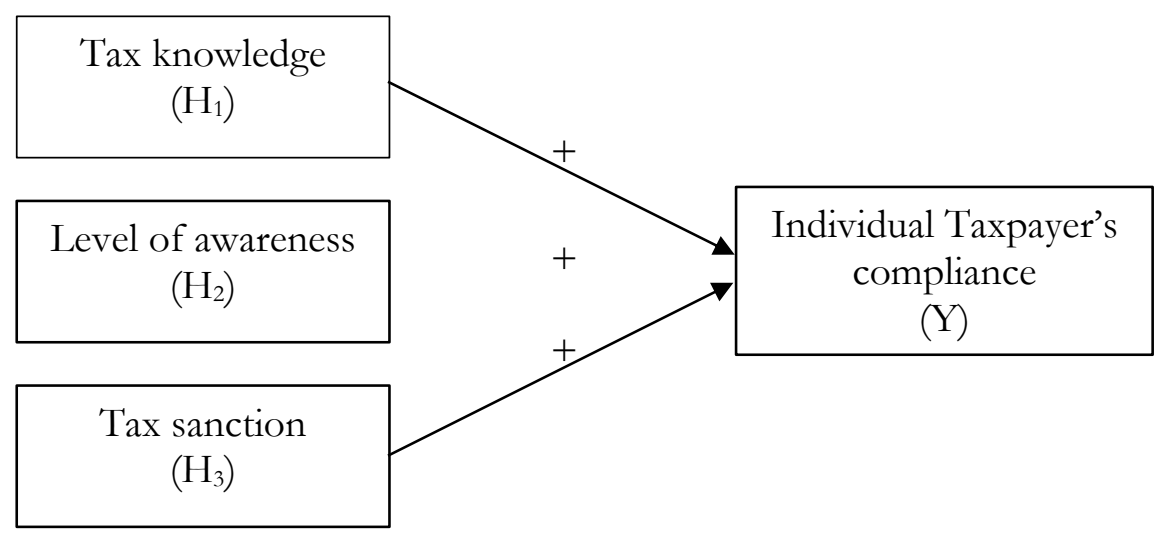

Figure 1. Research model

\section{Research Method}

\section{Population and Sample}

The research sample was all individual taxpayers who were running business and doing freelance work in Pontianak City. The sampling technique was random sampling to those individual taxpayers who were running business and doing freelance work and registered at KPP Pratama Pontianak.

The type of data used was primary data which were directly acquired from survey results. The survey results were collected by randomly distributing questionnaires to the individual taxpayers who were running business and doing freelance work and registered at KPP Pratama Pontianak.

\section{Operational Definition and Variable Measurement}

The variables were grouped into two, namely dependent variable and independent variable. Taxpayer's compliance was dependent variable; meanwhile, independent variable involved knowledge on taxation, level of awareness, and tax sanction. The operational definition and measurement of each variable is described below.

a. Knowledge on Taxation

Knowledge on taxation was knowledge about the concepts of general provisions in taxation, types of taxes prevailing in Indonesia including subject of tax, object of tax, tax tariff, computation of tax payable, recording of tax payable, and how to fill in tax report (Khasanah \& Novi, 2016). 
b. Level of Awareness

Level of awareness is a condition where a taxpayer knows, understands, and applies the provisions of taxation correctly and willingly. Taxpayer's awareness is evidence of the comprehension of the taxpayer on the meaning of tax (Jatmiko, 2006).

c. Tax Sanction

Tax sanction was a guarantee that the provisions of taxation rules and regulations (taxation norms) would be followed/obeyed/complied with. In other words, tax sanction was a preventive tool in order to keep taxpayers from violating taxation norms (Erawati \& As'ari, 2018).

d. Taxpayer's Compliance

Compliance is a motivation of an individual, group, or organization to do or not to do things as stipulated in the regulation. An individual compliance was an interaction between individual, group, and organization behaviors. In other words, tax compliance was an individual or taxpayer's compliance with the taxation laws and regulations (Jatmiko, 2006).

The scale of measurement used to calculate those four variables was Likert scale which was designed to examine how strong the subject agreed with a statement (Sekaran \& Bougie, 2013). The Likert scale was designed as follows:

- $\quad$ Value 1 = Strongly Disagree (SD)

- $\quad$ Value 2 = Disagree $(\mathrm{D})$

- $\quad$ Value $3=\operatorname{Neutral}(\mathrm{N})$

- $\quad$ Value $4=$ Agree (A)

- $\quad$ Value 5 = Strongly Agree $(\mathrm{SA})$

Table 1. Question Indicator

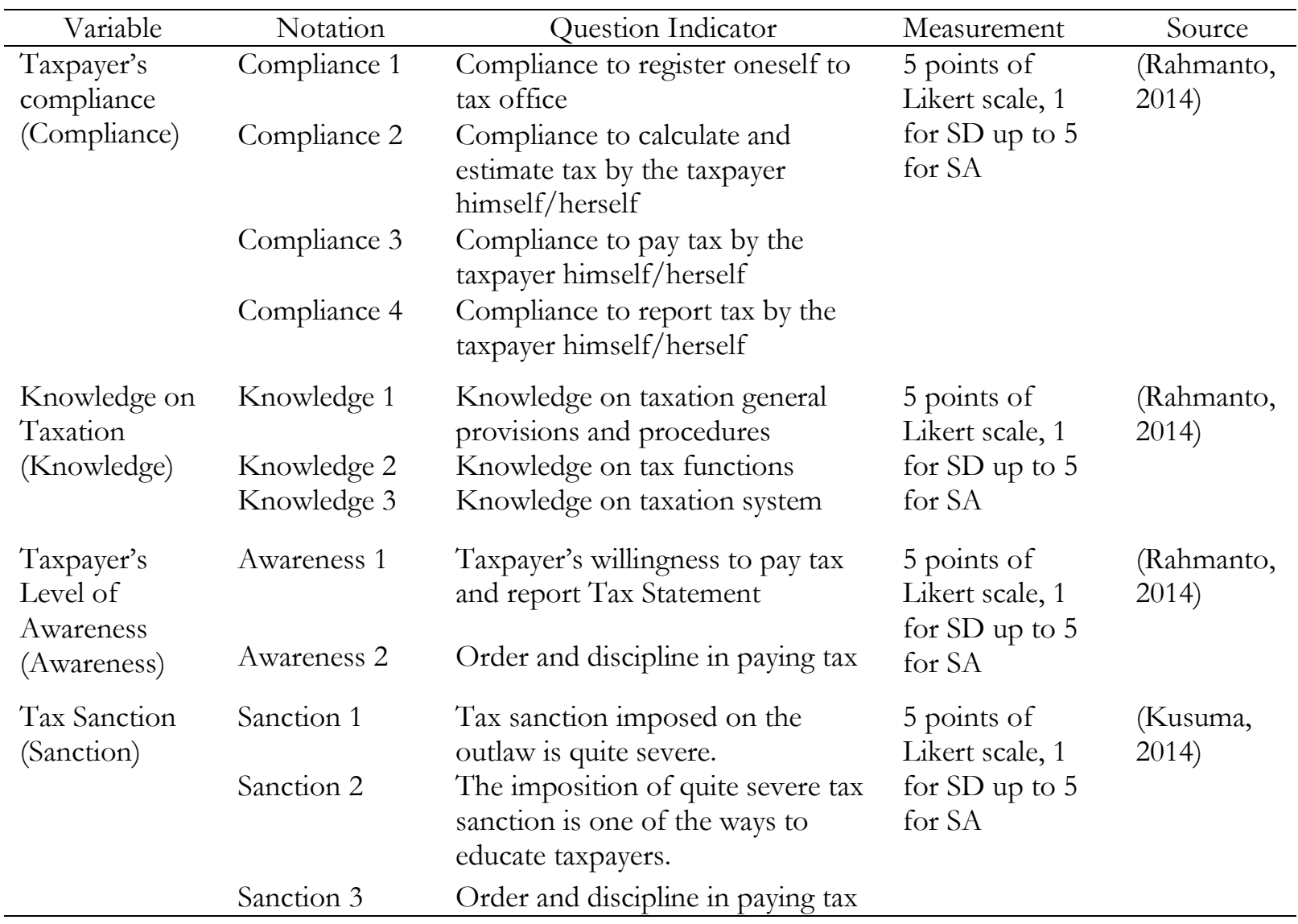


The method of data analysis used to test the hypotheses was double linear regression analysis which contained interactions among independent variables. The regression model is as follows.

$\mathrm{Y}=\alpha+\beta_{1} \mathrm{X}_{1}+\beta_{2} \mathrm{X}_{2}+\beta_{3} \mathrm{X}_{3}+\mathrm{e}$

where:

Y: Taxpayer's compliance

$a:$ Constants

$\beta:$ Regression coefficient

$X_{1}$ : Knowledge on taxation

$X_{2}$ : Level of awareness

$X_{3}:$ Tax sanction

$e:$ Error rate

The data quality test was conducted using classic assumption tests, namely normality test, multicollinearity test, and heteroscedasticity test.

\section{Results and Discussion}

The data used in this research was primary data obtained using survey by randomly distributing questionnaires to the individual taxpayers who were running business or doing freelance work in Pontianak City. The number of respondents was 50 individual taxpayers in Pontianak City.

Table 2 shows that the total questionnaires distributed were 50 , but the questionnaires which were eligible to analyze were only 47 . Based on gender, 47 respondents consisted of dominantly male numbering 30 people or $63.8 \%$. Furthermore, it can be noted that the majority of respondents' age was between $21-30$ years, as many as 22 people or $46.8 \%$.

Meanwhile, the types of work of respondents was grouped into two in line with the research object, namely business and freelance work. The number of respondents running business was 43 people or $91.4 \%$, and the number of freelance workers was four respondents or $8.5 \%$. The types of businesses registered included coffee shop, leather handicraft, grocery store, etc. Additionally, the freelance work listed was notary and specialist doctor.

Table 2. Respondents Profile

\begin{tabular}{lcc}
\hline Sample Distribution & Number & Percentage \\
\hline Questionnaires distributed & 50 & $100 \%$ \\
Incomplete questionnaires & 1 & $2 \%$ \\
Unreturned questionnaire & 2 & $4 \%$ \\
Total of Applicable questionnaires & 47 & $94 \%$ \\
Gender & & \\
Male & 30 & $63.80 \%$ \\
Female & 17 & $36.20 \%$ \\
Age & & \\
$10-20$ years & 1 & $2.10 \%$ \\
$21-30$ years & 22 & $46.80 \%$ \\
$31-40$ years & 13 & $27.60 \%$ \\
$41-50$ years & 7 & $14.90 \%$ \\
$>50$ years & 4 & $8.50 \%$ \\
Employment & & \\
Entrepreneur & 43 & $91.40 \%$ \\
Freelance worker & 4 & $8.50 \%$ \\
\hline
\end{tabular}

Source: Result of primary data analysis, 2018 


\section{Descriptive Analysis}

Table 3 shows that the summary of descriptive analysis result of the variables of knowledge on taxation $\left(\mathrm{X}_{1}\right)$, level of awareness $\left(\mathrm{X}_{2}\right)$, tax sanction $\left(\mathrm{X}_{3}\right)$, and taxpayer's compliance $(\mathrm{Y})$.

Table 3. Descriptive Statistics

\begin{tabular}{lccc}
\hline Variable & $\mathrm{N}$ & Mean & Std. Deviation \\
\hline Knowledge on taxation & 47 & 24.0000 & 3.90095 \\
Level of awareness & 47 & 21.8723 & 4.06799 \\
Tax sanction & 47 & 16.2766 & 4.01466 \\
Taxpayer's compliance & 47 & 35.5532 & 6.48345 \\
\hline
\end{tabular}

\section{Classic Assumption Test}

The classic assumption test used three types of tests, namely normality test, multi collinearity test, and heteroscedasticity test. Based on the normality test as shown in Table 4, the probability value of this study was 0.840 which was more than 0.05 , so it can be concluded that the data could be used in the study because the data were normally distributed.

Table 4. Result of Normality Test

\begin{tabular}{lc}
\hline & Unstandardized Residual \\
\hline $\mathrm{N}$ & 47 \\
Normal Parameters a.b Mean & .0000000 \\
Std. Deviation & 3.40497882 \\
Most Extreme Differences Absolute & .123 \\
Positive & .103 \\
Negative & -.123 \\
Test Statistic & .840 \\
Asymp. Sig. (2-tailed) & .480 \\
\hline
\end{tabular}

Based on the result of multicollinearity test as shown in Table 5, the tolerance values of the three variables were above 0.10 , and VIF values the variables were below 10 ; thus, it can be concluded that the data were eligible to be used in the study since there was no issue of multicollinearity.

Table 5 . Multicollinearity Test

\begin{tabular}{ccc}
\hline Model & $\begin{array}{c}\text { Collinearity Statistics } \\
\text { Tolerance }\end{array}$ & VIF \\
\hline $\mathrm{X}_{1}$ & 0.331 & 3.220 \\
$\mathrm{X}_{2}$ & 0.251 & 3.979 \\
$\mathrm{X}_{3}$ & 0.338 & 2.958 \\
\hline
\end{tabular}

The result of heteroscedasticity test shown in Figure 2 indicated that the dots were distributed from under 0 to 0 on $\mathrm{Y}$ axis and did not form a particular pattern so that it can be assumed that there was no issue of heteroscedasticity in this regression test. 


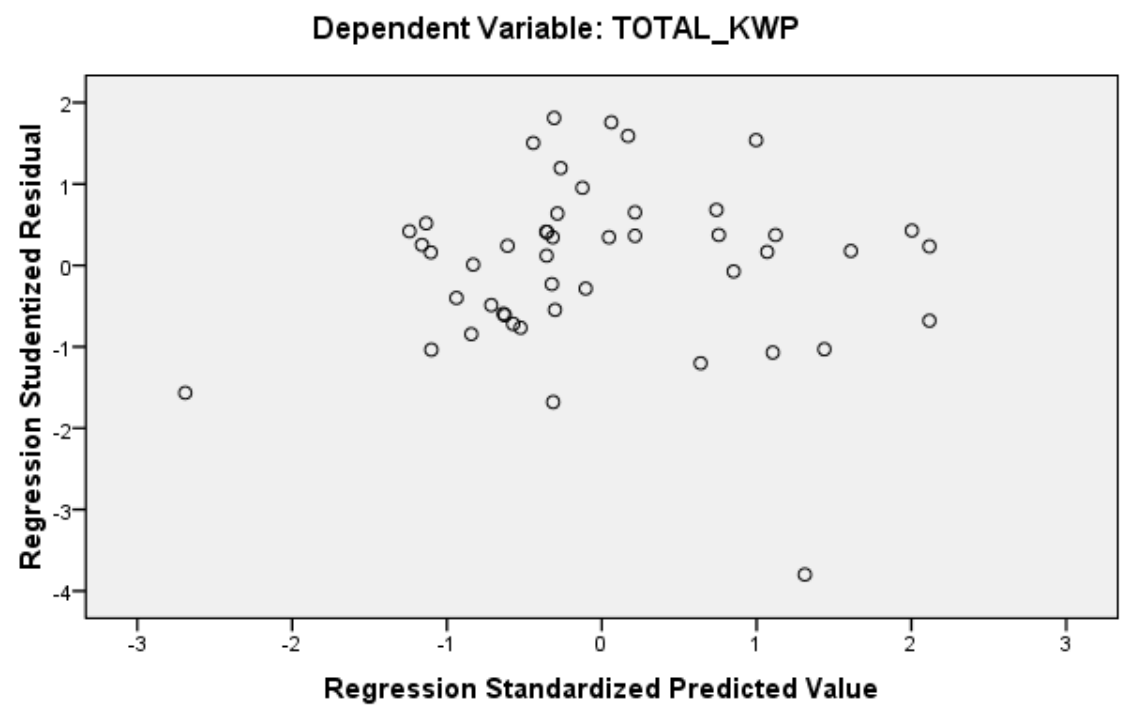

Figure 2. Heteroscedasticity test result

The result of multiple regression test on the three independent variables, namely knowledge on taxation, level of awareness, and tax sanction, as well as one dependent variable, taxpayer's compliance can be seen in Table 6 .

Table 6. Result of Regression Analysis

\begin{tabular}{clccl}
\hline Model & & $\begin{array}{c}\text { Unstandardized } \\
\text { Coefficients } \\
\text { B }\end{array}$ & Sig. & Conclusion \\
\hline 1 & (Constant) & 4.646 & 0.168 & \\
& Knowledge on taxation & 0.315 & 0.195 & $\mathrm{H}_{1}$ not supported \\
& Level of awareness & 0.846 & 0.002 & $\mathrm{H}_{2}$ supported \\
& Tax sanction & 0.299 & 0.187 & $\mathrm{H}_{3}$ not supported \\
\hline
\end{tabular}

Based on the result of multiple regression equation as shown in Table 6, the regression model obtained is as follows.

$\mathrm{Y}=4.646+0.315 \mathrm{X}_{1}+0.846 \mathrm{X}_{2}+0.299 \mathrm{X}_{3}$

The hypothesis test used $\mathrm{T}$ test. It can be seen from the probability value generated from the calculation. Based on the data in Table 6 , it can be concluded that:

a) The constants amounting 4.646 showed that the independent variables (knowledge on taxation, level of awareness, and tax sanction) could be assumed constant, so $\mathrm{Y}$ value (compliance of individual taxpayer running business or doing freelance work) was $4.646 \%$.

b) The coefficient of knowledge on taxation variable $\left(\mathrm{X}_{1}\right)$ was 0.315 which meant that every increase of $1 \%$ in knowledge on taxation would contribute an increase of $0.315 \%$ in the compliance of individual taxpayer running business or doing freelance work. The significance value as much as 0.195 could be assumed more than 0.05 which meant that knowledge on taxation did not influence the compliance of individual taxpayer running business or doing freelance work. Hence, the first hypothesis is not supported.

c) The coefficient of level of awareness variable $\left(\mathrm{X}_{2}\right)$ was 0.846 which meant that every increase of $1 \%$ in level of awareness would contribute an increase of $0.846 \%$ in the compliance of individual taxpayer running business or doing freelance work. The significance value amounting 
0.002 could be assumed lower than 0.05 which meant that level of awareness positively influenced the compliance of individual taxpayer running business or doing freelance work. Thus, the second hypothesis is supported.

d) The coefficient of tax sanction variable (X3) was 0.299 which meant that every increase of $1 \%$ in tax sanction would contribute an increase of $0.299 \%$ in the compliance of individual taxpayer running business or doing freelance work. The significance value as much as 0.187 could be assumed more than 0.05 which meant that tax sanction was not influential on the compliance of individual taxpayer running business or doing freelance work. Therefore, the third hypothesis is not supported.

\section{Discussion}

\section{Influence of knowledge on taxation on the compliance of individual taxpayer}

The result of the study has revealed that knowledge on taxation did not influence the compliance of individual taxpayers running business or doing freelance work at KPP Pratama Pontianak. The individual taxpayers acted and made decision to pay or report their taxes based on their level of knowledge on taxation. Based on the data of UNESCO (United Nations Educational, Scientific, and Cultural Organization), out of 61 countries, Indonesia ranks 60 in literacy. Consequently, the information on taxation which was disseminated by Ministry of Finance could not reach the community of Pontianak. However, from the study, it was found that the level of knowledge on taxation did not significantly influence the level of taxpayers' compliance to pay and report their taxes, especially in Pontianak. This study result supports the research conducted by Fernando and Arisman (2018); however, it contradicts the result of research carried out by Kesumasari and Suardana (2018).

\section{Influence of level of awareness on the compliance of individual taxpayer}

This study has proven that the level of awareness of the community in Pontianak to pay tax positively influenced the compliance of individual taxpayers running business or doing freelance work. This shows that the higher the level of awareness, the higher the level of compliance of the individual taxpayers running business or doing freelance work at KPP Pratama Pontianak.

The study result supports the research performed by Jatmiko (2006) and Arum (2012) which stated that the level of awareness of taxpayer was a condition where the taxpayer knew, understood, and applied the provisions of taxation correctly and willingly. The awareness of the taxpayer was the evidence of his/her understanding on taxation. In contrast, the result does not support the study conducted by Wilda (2015) which showed that the level of awareness of taxpayers were still low, so it did not encourage the tax compliance.

\section{Influence of tax sanction on the compliance of individual taxpayer}

As defined previously about tax sanction, concisely tax sanction was a preventive tool in order to keep taxpayers from violating taxation norms. The taxpayers only knew that the tax sanction would be implemented if they did not pay taxes only. In fact, tax sanction could be imposed not only based on the indicator of violation on tax payment, and the sanction could be in forms of either administrative or criminal sanction. The stricter sanction imposed on the taxation violator did not guarantee to improve the compliance of the taxpayers. This was in line with the result of this study which showed that tax sanction did not influence the compliance of individual taxpayers; therefore, the third hypothesis is refuted.

This finding supports the research carried out by Fernando and Arisman (2017), but it disproves the study of Arum (2012) which concluded that tax sanction impacted the compliance of individual taxpayer who was running business or doing freelance work. 


\section{Conclusion}

In conclusion, the result of analysis and discussion showed that knowledge on taxation and tax sanction did not influence the compliance of individual taxpayers running business or doing freelance work at KPP Pratama Pontianak. This showed that the low levels of knowledge on taxation and understanding on the procedures of tax payment and reporting owned by the taxpayers resulted from the lack of information dissemination by Ministry of Finance in Pontianak City. Similarly, the imposition of tax sanction did not guarantee the compliance of the taxpayers to report their taxes.

Meanwhile, level of awareness positively and significantly influenced the compliance of individual taxpayers who were running business or doing freelance work at KPP Pratama Pontianak. This showed that the higher the level of awareness owned by the taxpayers running business or doing freelance work, the higher their level of compliance.

It is suggested that the parties who have interest to improve the compliance of individual taxpayers, especially KPP Pratama Pontianak, disseminate more information and give follow-up consultation to maximize the tax revenue because Pontianak City still requires more funds collected from the community tax to improve the living standard and public facilities in Pontianak City.

\section{References}

Arum, H. P. (2012). Pengaruh kesadaran wajib pajak, pelayanan fiskus dan sanksi perpajakan terbadap kepatuhan wajib pajak orang pribadi yang melakukan kegiatan usaha dan pekerjaan bebas. Universitas Diponegoro.

Dewi, S. K., \& Merkusiwati, N. K. L. A. (2018). Pengaruh kesadaran wajib pajak, sanksi perpajakan, e-filing, dan tax amnesty terhadap kepatuhan pelaporan wajib pajak. E-Jurnal Akuntansi Universitas Udayana, 22(2), 1626-1655.

Erawati, T., \& As'ari, N. G. (2018). Pengaruh pemahaman peraturan perpajakan, kualitas pelayanan, kesadaran wajib pajak dan sanksi pajak terhadap kepatuhan wajib pajak orang pribadi. Jurnal Akuntansi Dewantara, 2(1), 46-55.

Fernando, \& Arisman, A. (2018). Pengaruh sosialisasi perpajakan , pengetahuan perpajakan , dan sanksi perpajakan terhadap kepatuhan wajib pajak orang pribadi. MDP Business School, 1, 114.

Ginting, A. V. L. (2017). Peran motivasi dan pengetahuan perpajakan terhadap kepatuhan wajib pajak. Jurnal Riset Ekonomi, Manajemen, Bisnis dan Akuntansi, 5(2), 1998-2006.

Heider, F. (1958). The psychology of interpersonal relations. New York: Wiley.

Jatmiko, A. N. (2006). Pengaruh sikap wajib pajak pada pelaksanaan sanksi denda, pelayanan fiskus dan kesadaran perpajakan terhadap kepatuhan wajib pajak. Universitas Diponegoro.

Kesumasari, N. K. I., \& Suardana, K. A. (2018). Pengaruh pengetahuan perpajakan, kesadaran dan pengetahuan tax amnesty pada kepatuhan WPOP di KPP pratama Gianyar. E-Jurnal Akuntansi Universitas Udayana, 22(2), 1503-1529.

Khasanah, S. N., \& Novi, A. (2016). Pengaruh pengetahuan perpajakan, modernisasi sistem administrasi perpajakan, dan kesadaran wajib pajak terhadap kepatuhan wajib pajak pada kantor wilayah direktorat jenderal pajak Daerah Istimewa Yogyakarta tahun 2013. Jurnal Profita, 8, 1-13.

Kontan.co.id. (2018). Penerimaan pajak triwulan I 2018 tumbuh 16,21\%. Retrieved from https://nasional.kontan.co.id/news/penerimaan-pajak-triwulan-i-2018-tumbuh-1621

Kusuma, R. S. (2010). Penggunaan internet oleh dosen berdasar gender. Komuniti, VIII(1), 53-63. 
Muliari, N. K., \& Setiawan, P. E. (2011). Pengaruh persepsi tentang sanksi perpajakan dan kesadaran wajib pajak pada kepatuhan pelaporan wajib pajak orang pribadi di kantor pelayanan pajak pratama Denpasar Timur. Jurnal Ilmiah Akuntansi dan Bisnis, 6(1), 1-23.

Rahmanto, B. W. (2014). Pengaruh pemahaman peraturan pajak, sanksi denda, dan kesadaran wajib pajak, terhadap kepatuban wajib pajak orang pribadi di kantor pelayanan pajak pratama Yogyakarta. Universitas Negeri Yogyakarta.

Robbins, S. P. (1996). Perilaku organisasi : konsep kontroversi dan aplikasi. Jakarta: Prenhallindo.

Rustiyaningsih, S. (2012). Faktor-faktor yang mempengaruhi kepatuhan wajib pajak. Widya Warta, 35(2), 44-54.

Sekaran, U., \& Bougie, R. (2013). Research methods for business (6th ed.). New York: John Wiley \& Sons.

Setiawan, D., Kurniawan, B., \& Payamta. (2018). Dampak penggunaan e-filling terhadap kepatuhan wajib pajak: peran perilaku wajib pajak sebagai variabel mediasi. Jurnal Akuntansi dan Auditing Indonesia, 22(1), 12-24

Setiyani, N. M., Andini, R., \& Oemar, A. (2018). Pengaruh motivasi wajib pajak dan pengetahuan perpajakan terhadap kepatuhan wajib pajak orang pribadi dengan kesadaran wajib pajak sebagai variabel intervening. Journal of Accounting, 4(4), 1-18.

Suntono., Kartika, A., \& Sudarsi, S. (2015). Peningkatan kepatuhan wajib pajak dalam perspektif teori prospek (studi empirik pada UMKM di Demak). In Procedings Management Dynamics Conference, Semarang.

Suprianto, E. (2011). Perpajakan Di Indonesia. Yogyakarta: Graha Ilmu.

TribunPontianak.com. (2018). Tingkat kesadaran wajib pajak non-karyawan di KPP Pontianak masih rendah. Retrieved from http://pontianak.tribunnews.com/2018/01/12/tingkatkesadaranwajib-pajak-non-karyawan-di-kpp-pontianak-masih-rendah

Undang-Undang nomor 28 tahun 2007 tentang ketentuan umum dan tata cara perpajakan (KUP).

Wilda, F. (2015). Pengaruh kesadaran wajib pajak, pelayanan fiskus dan sanksi pajak terhadap WPOP yang melakukan kegiatan usaha dan pekerjaan bebas. Jurnal Akuntansi, 3(1), 1-20. 